It is in the scientific work which falls directly under the Ministry of Defence that cuts seem most likely. The Royal Navy, for example, spends a total of $£ 34 \cdot 6$ million on activities classified as research and development. About one-third of this goes on weapon systems and radio and navigation equipment. The Army spends about $£ 21$ million, $£ 5$ million of it in industry. It supports several research establishments, including the Chemical Defence Experimental Establishment and the Microbiological Research Establishment. Finally, there is the Meteorological Office, costing around $£ 6$ million per year, supported by the Royal Air Force.

\section{Teaching Adults}

THe demand for adult education is a "growing and not a diminishing problem", according to Mr Goronwy Roberts, Minister of State at the Department of Education and Science. Mr Roberts was opening a conference at Birkbeck College, London, convened to discuss the problems of the mature student. $\mathrm{Mr}$ Roberts encouraged those involved in part-time education in Britain; not only did it help occupational mobility, but it could perhaps do more, and he visualized tired middle-aged executives being revived by the study of Plato and Aristotle. On a more down to earth note, he had some sharp words to say to Colleges of Advanced Technology which had abandoned sandwich courses since becoming universities. "We are not, I hope, going to lose the sandwich courses," he soid, making a hope sound more like a challenge.

The address at the opening ceremony was given by Dr F. Cyril James, Principal Emeritus of McGill University, Montreal. Why, asked Dr James, was there still a need for part-time education, when government grants were available for most able students to take full-time courses? He gave four reasons; the need for higher degrees, supplying deeper and more specialized knowledge; the need for regular retraining; the changing pattern of employment"something like half the working population are today working at jobs that did not exist at the opening of the twentieth century"- -and finally, the fact that more than half the children in Britain give up full-time education as soon as they can, at the age of 15 . Parttime students did have different problems from regular ones, he thought; they needed libraries and laboratories open until a late hour every night of the week, and on Saturdays and Sundays. Correspondence courses and a proper use of television as an educational medium could also help.

During the conference itself, $\mathrm{Mr}$ G. O. Arlt, President of the Council of Graduate Schools in the United States, gave details of the numbers of graduate part-time students in America. Despite difficulties of definition, which make it possible for the Ivy League universities to deny that they have any parttime students at all, while the California State Colleges, anxious to document their services to the community, claim 28,738 part-time and only 5,536 full-time students, the US Office of Education reported in 1965 a total of 477,535 graduate students, of whom 280,714 (59 per cent) were part-time. The wastage among part-time students is worse than that among full-timers-" "There appears to be a staggering attrition rate, probably as high as 60 per cent ... but no matter how you look at it, part-time graduate study is with us to stay, and universities may as well abandon their futile efforts to exorcise the phenomenon." Other delegates might have put the case for part-time study in more enthusiastic terms, but probably agreed with the conclusion.

\section{Nice Work if You Can Get It}

RARELY can a House of Commons committee have produced a more scathing report than that published last week by the Committee of Public Accounts. It was investigating the case in which Bristol Siddeley Engines had overcharged the Ministry of Aviation (later Technology) for work done on the overhaul of Sapphire and Viper engines between 1959 and 1963, costing a total of $£ 16.5$ million. In March this year the company finally agreed to repay to the ministry $£ 3.96$ million, which includes an unspecified figure (about $£ 400,000$ ) for accidental double charging.

The committee's description of how the situation came about makes fascinating reading. In the end, nobody emerges with reputation unscathed-even the final settlement is criticized. A separate contract was placed each year, on a "price to be agreed" basis, for the stripping, inspection, reassembly and testing of each engine. In many cases the final price was not settled until a major part of the work had already been done, so that the company must have had a very firm idea of costs. Under the contract system, however, it was not obliged to reveal these to the ministry. After the Ferranti affair, in which Ferranti, Ltd., agreed to repay $\mathfrak{f 4 . 2 5}$ million excess profits made under the contract to produce the Bloodhound missile, the ministry seems to have smelt a rat. It asked BSE for costs incurred on past contracts, which were refused; BSE did admit, however, that reductions in prices for 1963-64 and 1964-65 might be necessary, and submitted new quotations which seem merely to have encouraged the ministry to probe further.

Much of the ethical weight of argument in the report hangs on what is meant by the "fair and reasonable" prices to which both the ministry and the company were contractually committed. The company argued that a total view of its government contracts should be taken, and that on this view it was not overcharging. The ministry, and the committee, did not accept this view. "Government support . . . can be properly given only by way of conscious decision . . . and not by submitting to overcharging, of which the government is unaware, on quite different contracts." On some contracts the profit on costs amounted to more than 150 per cent, and the average figure over the four years was 74 per cent.

The ministry is also blamed by the committee. Its performance "fell far short of an acceptable standard". Even after the discovery by the ministry of the size of the overcharging, things seem to have moved at a leisurely pace, with gaps of up to a month between letters from the ministry and replies from the company. The final settlement was reached quite quickly after a letter in which is recorded Mr John Stonehouse's view that it was "the most disturbing case he had come across in the whole of his public life". Even the final settlement gets its share of criticism; in the Ferranti case, the final settlement left the company with profits of 21.4 per cent on costs, although the contract had involved a new project with consequent risks. The 